\title{
Yield and Yield Components Response of tef (Eragrostis tef) Varieties to Seed Rates in the Highland Vertisols of North Shewa, Ethiopia
}

\author{
Mebrate Tamrat \\ Ethiopian Institute of Agricultural Research, Holetta Agricultural Research Center, P.O.Box 2003, Adiss Ababa \\ Ethiopia
}

\begin{abstract}
A field experiment was conducted at Enewari, Ethiopia to determine appropriate seed rate for broadcast planting of tef in the highland Vertisols during 2012 and 2014 from July to December. Factorial combination of two varieties ('Dega-tef' and 'Holetta-key') with six seed rates $(5,10,15,20,25$ and $30 \mathrm{~kg} / \mathrm{ha}$ ) was laid out in a randomized complete block design with three replications. Main effects of varieties and seed rates showed significant effect on some parameters considered including grain- and straw yield. Most of the interaction effects showed non-significant effect on most parameters measured. However, seed rate of 25 and $30 \mathrm{~kg} / \mathrm{ha}$ found to be economically optimum for variety 'Dega-tef' and 'Holetta-key', respectively, by showing highest net benefits and marginal rate of return. Accordingly, use of variety Dega-tef at a seed rate of $25 \mathrm{~kg} / \mathrm{ha}$ and variety Holetta-key at a seed rate of $30 \mathrm{~kg} \mathrm{ha}^{-1}$ found to be preferable under broadcast sowing of tef at Enewari and similar areas where feed shortage is very critical.
\end{abstract}

Keywords: Broadcast sowing, Economic analysis, Reduced seed rate, Tef intensification, Vertisols, Yield

DOI: $10.7176 /$ JNSR/9-13-04

Publication date:July $31^{\text {st }} 2019$

\section{Introduction}

Tef [Eragrostis tef (Zucc.) Trotter] is an exciting grain, ancient, minute in size, and packed with nutrition. It is believed to have originated in Ethiopia between 4,000 and 1,000 before Christ (BC) (Gamboa and vanEkris, 2008). According to Tareke et al. (2013), tef remains the favorite food crop for Ethiopians and is becoming an important health crop in Europe and the USA especially due to the absence of gluten in its grain. It can replace glutencontaining cereals in products such as pasta, bread, beer, cookies and pancakes (vanDelden et al., 2010).

In Ethiopia, it is cultivated in a wide range of environments and performs better than other cereals under adverse climatic and soil conditions (Tareke et al. 2013). Despite its importance, the productivity of tef is much lower than that of other cereals. The national average yield is about $1.6 \mathrm{t} / \mathrm{ha}$, as compared to $3.4 \mathrm{t} / \mathrm{ha}$ for maize and $2.5 \mathrm{t} / \mathrm{ha}$ for wheat (CSA, 2015). This is attributed to several yield-limiting factors. Lodging or the permanent displacement of the stem from the upright position is the major constraint limiting the productivity of the crop especially when it occurs during the grain-filling period (vanDelden et al., 2010). Lodging affects both the quality and quantity of the produce (Seyfu, 1997). Sub-optimum crop husbandry also contributes to reducing the yield of tef. For example, according to Tareke et al. (2013), broadcasting the seeds at higher rate of 25 to $50 \mathrm{~kg} / \mathrm{ha}$ results in increased plant density, which renders the crop prone to lodging and subsequently lead to poor yields in terms of both quality and quantity. In addition to this, the low national average is partly associated with constraints such as waterlogging, drought, frost, and nutrient limitation (Seyfu, 1997).

Efforts have been made in the past to implement different techniques and tools in order to improve tef productivity, which were not as such satisfactory in reducing lodging problem. However, recently another approach called "intensification or precision agriculture" or "System of Tef Intensification" (Tareke et al., 2013), has emerged in exploratory agronomic experiments in Ethiopia which have shown that grain and straw yields of tef can be "doubled or even tripled." Among which reducing the seed rate is one of the promising planting techniques used to minimize lodging of tef and produce higher yield under broadcast sowing. Accordingly, this study was conducted to determine optimum seed rate for broadcast sowing of tef on heavy Vertisols that could minimize lodging problem.

\section{Materials and Methods}

\section{Description of experimental site}

The experiment was conducted at Enewari, the research site of Debre Brehan Agricultural Research Center, in the year 2012 and 2014 from July to December on heavy Vertisols. The same experiment was conducted during 2013, however grasshopper affected it before germination and most plots failed to have sufficient stand. Hence, it has been excluded from analysis. The experimental site is located at latitude of $9^{0} 53^{\prime} \mathrm{N}$ and longitude of $39^{\circ} 10^{\prime} \mathrm{E}$ and an altitude of 2,665 meters above sea level (INFO ARARI, 2004). Soil test results indicated that the surface soil of the experimental field is clayey in texture with clay content of $66 \%, \mathrm{pH}$ of $6.69, \mathrm{CEC}$ of $54.26 \mathrm{Cmol}(+) / \mathrm{kg}$ 
soil), organic carbon of $1.15 \%$, base saturation of $84.23 \%$, total $\mathrm{N}$ of $0.088 \%$ and available $\mathrm{P}$ of $8.7 \mathrm{ppm}$.

\section{Treatments, experimental design and procedure}

Treatments consisted of complete factorial combination of two varieties ('Dega-tef' and 'Holetta-key') with six seed rates $(5,10,15,20,25$ and $30 \mathrm{~kg} / \mathrm{ha})$. The varieties were selected based on their difference in panicle- and seed color, as well as plant height while seed rates of 25 and $30 \mathrm{~kg} / \mathrm{ha}$ indicate blanket recommendations, which could be used as a control for the study area. The experiment was conducted in a randomized complete block design with three replications. The seeds were broadcasted by mixing with small size soil particle (used as spreader), but the seeds were not covered with extra soil. The gross plot size of $15 \mathrm{~m}^{2}$ ( $5 \mathrm{~m}$ length $\mathrm{x} 3 \mathrm{~m}$ width) was used. Blanket recommendation of $64-20 \mathrm{~kg} \mathrm{~N}-\mathrm{P} / \mathrm{ha}$, fertilizer nutrients was applied on each plot. All P and half of $\mathrm{N}$ was applied at planting while the remaining $\mathrm{N}$ was applied at tillering stage of the crop. Sowing was done on 01 August 2012 and 31 July 2014 while harvesting was done from mid-December to mid-January in both years. Twice hand weeding was undertaken to control weeds.

\section{Data collection and Measurement}

Data on plant height was taken from 10 randomly selected plants from central part of each plot while number of total- and productive tillers were counted from one square meter area. Aboveground dry biomass was measured in gram for plants harvested from the whole plot in 2012 and from $4 \mathrm{~m}^{-2}$ in 2014 after sun drying and converted to tons per hectare. Straw yield was obtained by deducting grain yield from the total sundried above ground dry biomass. Harvest index was calculated as a ratio of grain yield to the above ground dry biomass obtained from each net plot. Grain yield data was measured from the whole plot in 2012 and from $4 \mathrm{~m}^{-2}$ in 2014

Daily rainfall, maximum and minimum temperature data were recorded at Enewari metrology station by employees of national meteorology agency. Then secondary data was collected from National Meteorology Agency, Kombolcha branch directorate (unpublished data).

\section{Data analysis}

Data collected were subjected to the analysis of variance (ANOVA) following the statistical procedures applied for two factors factorial experiments by using SAS Software version 9.0, Copyright (c) 2002 by SAS Institute Inc. Mean comparison was performed by using Duncan's Multiple Range Test (DMRT) at 5\% level of significance upon obtaining significant F-values of the factors and interactions. Variance homogeneity test was performed before combining data by employing Bartlett's test (Gomez and Gomez, 1984).

\section{Economic analysis}

Partial budget analysis was done following the method of CIMMYT (1988). Mean grain- and straw yield was used to calculate gross benefit by multiplying with their respective field prices. The mean field price was obtained by simple assessment of farmers' prices near experimental field after harvest (January - February 2015). Accordingly, the prices of grain yield of variety Dega-tef and variety Holetta-key were found to be United States Dollar (USDsymbolized as $\$$ hereafter in the manuscript) 0.66 and 0.45 per kilogram, respectively. The variable costs included cost of seed during sowing (June 2014) and estimated as \$ 0.73 and 0.54 per kilogram for Dega-tef and Holettakey, respectively. The cost of fertilizer was not considered because it was applied uniformly to all plots. Cost of labor for weeding, harvesting, threshing, winnowing, packing and transporting per treatment was not considered because of difficulty in estimating as the experiment was done on a small plot. The average yield was adjusted downward to $10 \%$ assuming yield reduction by $10 \%$ if farmers managed the same trial. In order to use the marginal rate of return (MRR) as a basis for variety and seed rate recommendation, the minimum acceptable rate of return was set at $70 \%$. Treatments that have higher costs that vary but lower net benefit than treatments of lower cost with higher net benefit were considered to be dominated and were eliminated from further consideration.

\section{Results and Discussion \\ Weather condition for tef growth period}

According to unpublished data of National Metrological Agency, the total rainfall for the period of July to December, 2012 was $914.8 \mathrm{~mm}$ which is a little bit higher than that of the year $2014(816.8 \mathrm{~mm})$ for the same period. The highest rainfall was received in July and August in both years (Figure 1). The mean maximum temperature lacks trend (lower in some months and higher in other months) in both years, hence difficult to indicate its impact (Figure 1). On the other hand the mean minimum temperature showed decreasing trend from July to December for both years, except it begun to increase in December for the year 2012 (Figure 1). 


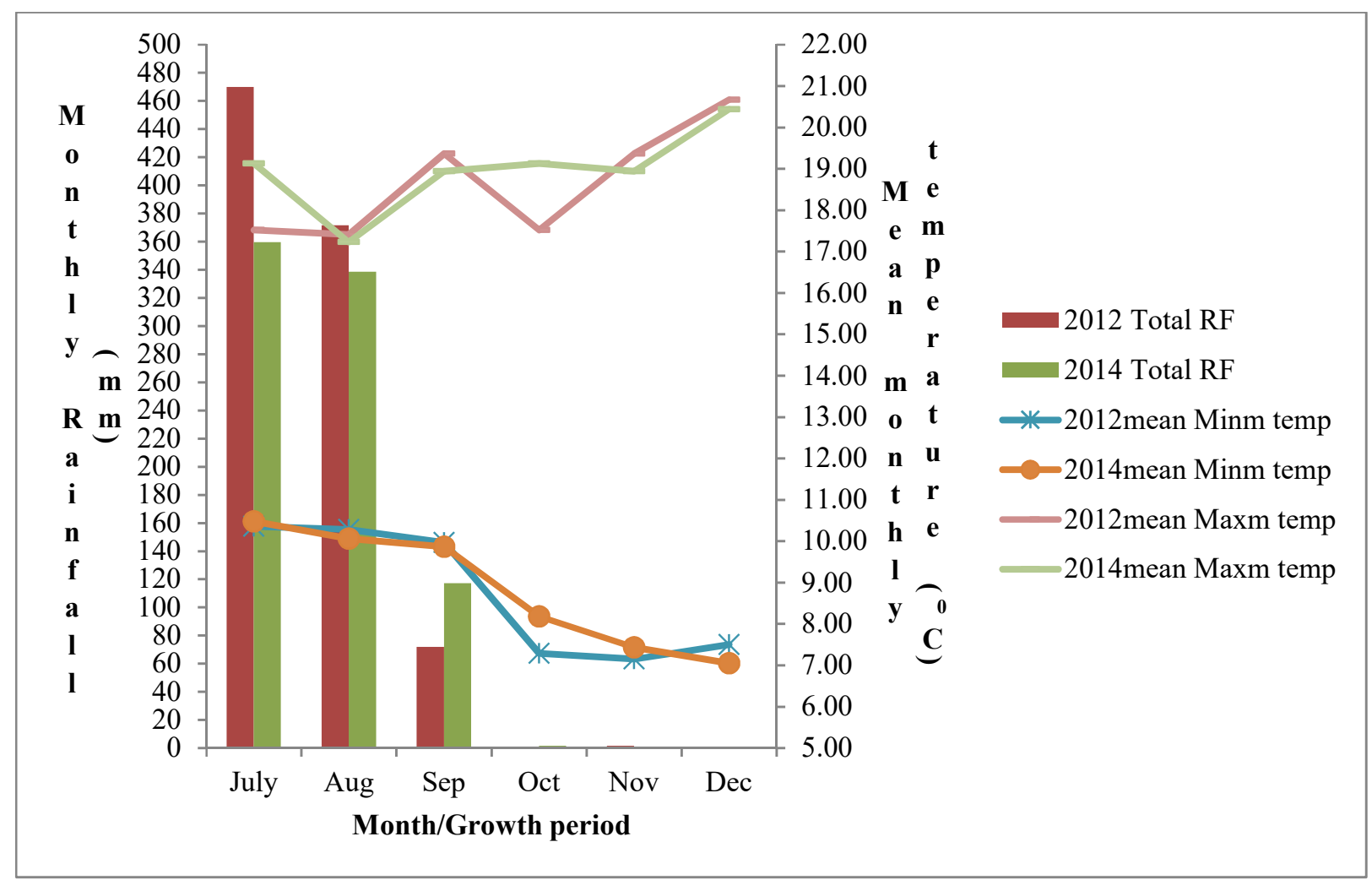

Figure 1. Monthly total rainfall $(\mathrm{mm})$ and mean temperature $\left({ }^{0} \mathrm{c}\right)$ for the period of 2012 and 2014 at Enewari Source: National Meteorology Agency Kombolcha branch directorate (unpublished data)

\section{Biological data}

According to combined analysis of variance, year showed significant $(\mathrm{P}<0.05)$ effect on all parameters measured. Most of the interaction effects including variety by seed rate and year by variety by seed rate showed nonsignificant effect on all parameters considered (Table 1). Hence, the main effects of variety and seed rates are considered in this paper.

Table 1. Mean squares of ANOVA for yield and some agronomic parameters of tef as affected by variety and seed rate at Enewari, combined over years (2013 to 2014)

\begin{tabular}{lccccccc}
\hline \multicolumn{1}{c}{$\begin{array}{c}\text { Source of } \\
\text { variation }\end{array}$} & Plant height & $\begin{array}{c}\text { Number of total } \\
\text { tillers }\end{array}$ & $\begin{array}{c}\text { Number of } \\
\text { productive tillers }\end{array}$ & $\begin{array}{c}\text { Above } \\
\text { dround } \\
\text { diomass }\end{array}$ & $\begin{array}{c}\text { Grain } \\
\text { yield }\end{array}$ & $\begin{array}{c}\text { Straw } \\
\text { Yield }\end{array}$ & $\begin{array}{c}\text { Harvest } \\
\text { index }\end{array}$ \\
\hline Year (yr) & $3954.57^{* *}$ & $11188815.13^{* *}$ & $11871440.22^{* *}$ & $25.48^{*}$ & $1.27^{*}$ & $15.40^{* *}$ & $0.02^{* *}$ \\
Rep*yr & 33.46 & 488684.28 & 422615.76 & 1.35 & 0.14 & 0.66 & 0.0007 \\
Variety (var) & $2466.36^{* *}$ & $2586675.13 \mathrm{~ns}$ & $2024742.72 \mathrm{~ns}$ & $4.14^{* *}$ & $0.18^{*}$ & $2.60 \mathrm{~ns}$ & $0.002 \mathrm{~ns}$ \\
Seed rate (sr) & $39.09 \mathrm{~ns}$ & $33879147.75^{* *}$ & $3674567.19^{*}$ & $1.58^{* *}$ & $0.06 \mathrm{~ns}$ & $1.07^{* *}$ & $0.002^{* *}$ \\
yr*var & $2398.93^{* *}$ & $933661.12^{*}$ & $1021020.50^{*}$ & $1.34 \mathrm{~ns}$ & $0.002 \mathrm{~ns}$ & $1.44^{* *}$ & $0.005^{* *}$ \\
yr*sr & $28.12 \mathrm{~ns}$ & $4116.49 .19 \mathrm{~ns}$ & $399863.19 \mathrm{~ns}$ & $0.19 \mathrm{~ns}$ & $0.03 \mathrm{~ns}$ & $0.12 \mathrm{~ns}$ & $0.0005 \mathrm{~ns}$ \\
var*sr & $46.21 \mathrm{~ns}$ & $479494.99 \mathrm{~ns}$ & $484491.62^{*}$ & $0.35 \mathrm{~ns}$ & $0.04 \mathrm{~ns}$ & $0.15 \mathrm{~ns}$ & $0.00008 \mathrm{~ns}$ \\
yr*var*sr & $84.11 \mathrm{~ns}$ & $74449.39 \mathrm{~ns}$ & $72349.80 \mathrm{~ns}$ & $0.44 \mathrm{~ns}$ & $0.07 \mathrm{~ns}$ & $0.18 \mathrm{~ns}$ & $0.0002 \mathrm{~ns}$ \\
Error & 56.35 & 213708.84 & 189040.69 & 0.3324 & 0.043 & 0.164 & 0.0003 \\
\hline
\end{tabular}

F test for year was performed by using Rep (yr) as a denominator while $\mathrm{F}$ test for main effects was performed by using significant year by factor interaction as a denominator; otherwise, the pooled error mean square is used as a denominator, $* *, *=$ significant at $1 \%$ and $5 \%$ level of significance respectively, ns=non-significant

\section{Effect of varieties}

Main effect of variety showed highly significant $(\mathrm{P}<0.01)$ effect on plant height and above ground dry biomass while significant $(\mathrm{P}<0.05)$ effect on grain yield (Table 2$)$. Accordingly, variety 'Dega-tef' was significantly taller (over $21.43 \%$ ) than 'Holetta-key'. Similarly, it produced significantly highest (over $8.74 \%$ and $4.81 \%$ ) above 
ground dry biomass and grain yield, respectively, than 'Holetta-key'. The difference was probably related to genotypic effect. Seyfu (1997) reported presence of high variability for grain yield per plant, straw yield per plant and harvest index among 2,255 pure line accessions of tef. Similarly, Amare and Adane (2014) reported significant differences between two tef varieties ('Quncho' and 'Mechrie') for plant height, number of total tillers, effective tillers, and biomass at Sirinka in Ethiopia.

\section{Effect of seed rates}

Main effect of seed rate showed significant $(\mathrm{P}<0.05)$ effect on number of total tillers, number of productive tillers, above ground dry biomass, straw yield and harvest index (Table 1). There was significant increase (108.7, 108.2, 18.1 and $25.16 \%$ ) in number of total tillers $\mathrm{m}^{-2}$, number of productive tillers $\mathrm{m}^{-2}$, aboveground dry biomass and straw yield, respectively, as seed rate increased from 5 to $30 \mathrm{~kg} / \mathrm{ha}$ which was probably related to increase in the number of plants per unit area. On the other hand, the lowest seed rate of $5 \mathrm{~kg} /$ ha produced $11.11 \%$ harvest index advantage over the highest seed rate of $30 \mathrm{~kg} /$ ha (Table 2). This was probably related to higher plant-to-plant competition at higher plant densities for resources such as moisture, nutrients and light, which might favour higher total dry matter production than grain yield. Rifaee et al. (2004) indicated that increase in biological yield as the number of plants per unit area increased with no significant increases in seed yield, leads to lower harvest indices. Though there was no significant difference among seed rates on grain yield, the highest grain yield was obtained from highest seed rate of $30 \mathrm{~kg} /$ ha (Table 2) that should be verified by economic analysis. Similarly, grain yield was positively and highly significantly correlated with biomass and straw yield while positively correlated with number of total- and productive tillers. On the other hand, it was negatively and significantly correlated with plant height and harvest index (Table 3). It is also to be noted that tef straw is highly preferred by cattle over the straw of other cereals and demands high prices in the markets (Seyfu, 1997). Hence, it should be considered side-byside as the highest straw yield also obtained from the highest seed rate (Table 2). Therefore, under broadcast sowing of tef at Enewari and similar areas, reducing the seed rate may help to minimize lodging but, not helpful to produce higher grain- and straw yield.

In general, the highest yield was obtained in the second year that was probably related to highest rainfall received in the months of September and October that may favoured better grain setting (separate data not shown). In addition to this, the rainfall received in November in the first year may force grains to shatter (Figure 1).

Table 2. Main effects of variety and seed rate on yield and some agronomic parameters of tef at Enewari, combined over years (2013 to 2014)

\begin{tabular}{|c|c|c|c|c|c|c|c|}
\hline & Plh (cm) & $\begin{array}{l}\text { NTT } \\
\left(\mathrm{m}^{-2}\right)\end{array}$ & $\operatorname{NPT}\left(m^{-2}\right)$ & $\mathrm{BM}(\mathrm{t} / \mathrm{ha})$ & $\begin{array}{c}\text { GY } \\
(\mathrm{t} / \mathrm{ha})\end{array}$ & $\begin{array}{c}\text { SY } \\
(\mathrm{t} / \mathrm{ha})\end{array}$ & $\mathrm{HI}$ \\
\hline \multicolumn{8}{|l|}{ Variety } \\
\hline 'Dega-tef' & 66.3 & $1,974.7$ & $1,937.9$ & 5.97 & 2.18 & 3.79 & 0.37 \\
\hline 'Holetta-key' & 54.6 & $2,353.8$ & $2,273.3$ & 5.49 & 2.08 & 3.41 & 0.38 \\
\hline $\operatorname{LSD}(5 \%)$ & 3.57 & ns & ns & 0.27 & 0.099 & $\mathrm{~ns}$ & $\mathrm{~ns}$ \\
\hline \multicolumn{8}{|c|}{ Seed rate $(\mathrm{kg} / \mathrm{ha})$} \\
\hline 5 & 62.0 & $1,374.5$ & $1,341.3$ & 5.26 & 2.09 & 3.18 & 0.40 \\
\hline 10 & 62.3 & $1,739.2$ & $1,708.7$ & 5.54 & 2.07 & 3.47 & 0.37 \\
\hline 15 & 61.6 & $2,089.1$ & $2,028.3$ & 5.48 & 2.06 & 3.42 & 0.38 \\
\hline 20 & 60.2 & $2,194.5$ & $2,098.7$ & 5.89 & 2.14 & 3.74 & 0.36 \\
\hline 25 & 58.2 & $2,717.5$ & $2,664.1$ & 6.03 & 2.21 & 3.82 & 0.37 \\
\hline 30 & 58.5 & $2,870.8$ & $2,792.3$ & 6.21 & 2.23 & 3.98 & 0.36 \\
\hline $\operatorname{LSD}(5 \%)$ & ns & 380.36 & 357.73 & 0.47 & $\mathrm{~ns}$ & 0.33 & 0.014 \\
\hline Mean & 60.5 & 2164.3 & 2105.5 & 5.73 & 2.13 & 3.60 & 0.37 \\
\hline CV (\%) & 12.41 & 21.36 & 20.65 & 10.05 & 9.76 & 11.26 & 4.59 \\
\hline
\end{tabular}

$\mathrm{LSD}=$ Least significant difference at 5\% level; $\mathrm{CV}=$ Coefficient of variation; Means in column followed by the same letters are not significantly different at $5 \%$ level of significance, Plh=Plant height, NTT=Number of total tillers, NPT=Number of productive tillers, $\mathrm{BM}=$ above ground dry biomass, $\mathrm{SY}=\mathrm{Straw}$ yield, $\mathrm{HI}=$ Harvest index, $\mathrm{GY}=$ Grain yield 
Table 3. Correlation coefficients between tef studied characters at Enewari

\begin{tabular}{lccccccc}
\hline & Plh & NTT & NPT & BM & SY & HI & GY \\
\hline Plh & - & & & & & \\
NTT & $-0.511^{* *}$ & - & & & & \\
NPT & $-0.518^{* *}$ & $0.996^{* *}$ & - & & & \\
BM & $-0.319^{* *}$ & $0.582^{* *}$ & $0.590^{* *}$ & - & & \\
SY & $-0.292^{*}$ & $0.600^{* *}$ & $0.608^{* *}$ & $0.987^{* *}$ & - & \\
HI & $0.144 \mathrm{~ns}$ & $-0.545^{* *}$ & $-0.551^{* *}$ & $-0.707^{* *}$ & $-0.807^{* *}$ & - \\
GY & $-0.351^{* *}$ & $0.454^{* *}$ & $0.459^{* *}$ & $0.899^{* *}$ & $0.818^{* *}$ & $-0.337^{* *}$ & - \\
\hline
\end{tabular}

Plh=Plant height, NTT=Number of total tillers, NPT=Number of productive tillers, $\mathrm{BM}=$ above ground dry biomass, $\mathrm{SY}=$ Straw yield, $\mathrm{HI}=$ Harvest index, $\mathrm{GY}=$ Grain yield

\section{Economic analysis}

Economic analysis for mean grain- and straw yield was done based on CIMMYT (1988). As indicated in Tables 4 and 5, variety 'Dega-tef' had highest net benefit of 1,641.69 \$/ha with marginal rate of return of 2,986.78\% at a seed rate of $25 \mathrm{~kg} / \mathrm{ha}$ while variety 'Holetta-key' had highest net benefit of 1,099.10 \$/ha with marginal rate of return of $322.36 \%$ at a seed rate of $30 \mathrm{~kg} / \mathrm{ha}$.

Table 4. Dominance and marginal rate of return analysis for the effect of seed rate and varieties on grain- and straw yield (t/ha) of tef variety 'Dega tef' at Enewari, combined over years (2012 and 2014)

\begin{tabular}{|c|c|c|c|c|c|c|c|c|}
\hline \multirow[b]{2}{*}{$\begin{array}{l}\text { Seed } \\
\text { Rate } \\
(\mathrm{kg} / \mathrm{ha})\end{array}$} & \multicolumn{2}{|c|}{ Average yield (t/ha) } & \multicolumn{2}{|c|}{ Adjusted yield (t/ha) } & \multirow{2}{*}{$\begin{array}{c}\text { GB } \\
\text { (\$/ha) } \\
\text { (sum of } \\
\text { GY\& } \\
\text { SY) }\end{array}$} & \multirow{2}{*}{$\begin{array}{c}\text { TCV } \\
\text { (\$/ha) } \\
\text { (sum of } \\
\text { GY\& } \\
\text { SY) }\end{array}$} & \multirow{2}{*}{$\begin{array}{l}\text { NB } \\
\text { (\$/ha) } \\
\text { (sum of } \\
\text { GY\& } \\
\text { SY) }\end{array}$} & \multirow[b]{2}{*}{$\begin{array}{c}\operatorname{MRR}(\%) \\
\text { (sum of } \\
\text { GY\& SY) }\end{array}$} \\
\hline & Grain yield & $\begin{array}{l}\text { Straw } \\
\text { yield }\end{array}$ & $\begin{array}{c}\text { Grain yield } \\
(\mathrm{GY})\end{array}$ & $\begin{array}{c}\text { Straw yield } \\
\text { (SY) }\end{array}$ & & & & \\
\hline 5 & 2.11 & 3.28 & 1.90 & 2.95 & $1,459.98$ & 3.64 & $1,456.34$ & \\
\hline 10 & 2.03 & 3.52 & 1.83 & 3.17 & $1,427.58$ & 7.27 & $1,420.31$ & $\mathrm{D}$ \\
\hline 15 & 2.12 & 3.69 & 1.91 & 3.32 & $1,491.75$ & 10.91 & $1,480.84$ & 337.00 \\
\hline 20 & 2.19 & 3.92 & 1.97 & 3.53 & $1,547.82$ & 14.55 & $1,533.27$ & $1,440.38$ \\
\hline 25 & 2.35 & 4.19 & 2.12 & 3.77 & $1,659.87$ & 18.18 & $1,641.69$ & $2,986.78$ \\
\hline 30 & 2.29 & 4.15 & 2.06 & 3.74 & $1,621.71$ & 21.82 & $1,599.89$ & $\mathrm{D}$ \\
\hline
\end{tabular}

$G B=$ Gross benefit, $T V C=$ Total costs that vary, $N B=$ Net benefits, $M R R=$ Marginal rate of return, $D=$ Dominated

Table 5. Dominance and marginal rate of return analysis for the effect of seed rate and varieties on grain- and straw yield ( $t$ /ha) of tef variety 'Holetta-key' at Enewari, combined over years (2012 and 2014)

\begin{tabular}{|c|c|c|c|c|c|c|c|c|}
\hline \multirow[b]{2}{*}{$\begin{array}{c}\text { Seed } \\
\text { Rate } \\
(\mathrm{kg} / \mathrm{ha})\end{array}$} & \multicolumn{2}{|c|}{ Average yield (t/ha) } & \multicolumn{2}{|c|}{ Adjusted yield (t/ha) } & \multirow{2}{*}{$\begin{array}{c}\text { GB } \\
\text { (\$/ha) } \\
\text { (sum of } \\
\text { GY\& } \\
\text { SY) }\end{array}$} & \multirow{2}{*}{$\begin{array}{l}\text { TCV } \\
\text { (\$/ha) } \\
\text { (sum of } \\
\text { GY\& } \\
\text { SY) }\end{array}$} & \multirow{2}{*}{$\begin{array}{l}\text { NB } \\
\text { (\$/ha) } \\
\text { (sum of } \\
\text { GY\& } \\
\text { SY) }\end{array}$} & \multirow[b]{2}{*}{$\begin{array}{c}\text { MRR(\%) } \\
\text { (sum of } \\
\text { GY\& SY) }\end{array}$} \\
\hline & Grain yield & $\begin{array}{l}\text { Straw } \\
\text { yield }\end{array}$ & $\begin{array}{c}\text { Grain yield } \\
(\mathrm{GY})\end{array}$ & $\begin{array}{c}\text { Straw yield } \\
(\mathrm{SY})\end{array}$ & & & & \\
\hline 5 & 2.07 & 3.07 & 1.86 & 2.76 & $1,031.76$ & 2.73 & $1,029.03$ & \\
\hline 10 & 2.11 & 3.41 & 1.90 & 3.07 & $1,069.38$ & 5.45 & $1,063.93$ & $1,283.09$ \\
\hline 15 & 2.00 & 3.15 & 1.80 & 2.84 & $1,008.45$ & 8.18 & $1,000.27$ & D \\
\hline 20 & 2.10 & 3.57 & 1.89 & 3.21 & $1,075.41$ & 10.91 & $1,064.50$ & 10.44 \\
\hline 25 & 2.05 & 3.45 & 1.85 & 3.11 & $1,047.60$ & 13.64 & $1,033.96$ & $\mathrm{D}$ \\
\hline 30 & 2.16 & 3.82 & 1.94 & 3.44 & $1,115.46$ & 16.36 & $1,099.10$ & 322.36 \\
\hline
\end{tabular}

\section{Conclusion}

Present study revealed that broadcast seeding of tef at lower seed rates could produce comparable yields to broadcasting of heavy seed rates that has been recommended previously. However, farmers of the study area give higher preference for the seed rate and varieties that can produce higher grain yield together with higher straw yield, because tef straw is valuable feed source for livestock at Enewari where feed shortage is very critical. Accordingly, it is mandatory to recommend the seed rates which could be reasonably preferable and/or acceptable by farmers. Hence, for broadcast sowing of tef in the highland Vertisols of North Shewa, use of variety 'Dega-tef' at a seed rate of $25 \mathrm{~kg} / \mathrm{ha}$ and variety 'Holetta-key' at a seed rate of $30 \mathrm{~kg} / \mathrm{ha}$ produced highest economic return. As variety 'Dega-tef' showed plastic yield response to a seed rate (from $15-25 \mathrm{~kg} / \mathrm{ha}$ ), farmers/producers who have limited access for resources could use it at a seed rate of 20 and $15 \mathrm{~kg} / \mathrm{ha}$ as secondary and tertiary choices, respectively. 


\section{Acknowledgements}

The authors would like to thank Amhara Region Agricultural Research Institute, Debre Brehan Research Center for financial and logistical support.

\section{References}

Amare Aleminew and Adane Legas. (2014). Determination of Seed Rate and Variety on the Growth and Yield of Tef. In: Proceedings of the sixth and seventh Annual Regional Conference on Completed Crops Research Activities. Tilahun Tadesse and Yeshitila Merene (Eds.). Amhara Agricultural Research Institute, Bahir Dar, Ethiopia. pp. 29-40.

CIMMYT (Centro internacional de mejoramiento de maiz y Trigo; International Maize and Wheat Improvement Center). (1988). From Agronomic Data to Farmer Recommendations: An Economics Training Manual, Completely Revised Edition, Mexico.

CSA (Central Statistical Agency). (2015). Agricultural sample survey 2014 / 2015 (2007 E.C). Report on area and production of major crops, volume I, statistical bulletin no. 578, Addis Ababa, Ethiopia.

Gamboa, P. A. and vanEkris, L. (2008). Tef: "Survey on the nutritional and health aspects of tef (Eragrostis tef)." memorias * red-alfa lagrotech * comunidad europea * Cartagena. http://www.doc-developpementdurable.org/file/Culture-plantes-alimentaires/

FICHES_PLANTES/teff/Survey\%20on\%20the \%20nutritional\%20and $\% 20$ health $\% 20$ aspects $\% 20$ of $\% 20$ teff .pdf. Accessed on 07 June 2017.

Gomez, K.A. and Gomez, A.A. (1984). Statistical Procedure for Agricultural Research, second edition. John Wiley and Sons. Inc.

INFO ARARI. (2004). Amhara Agricultural Research Institute (ARARI) Biometrics and Information Technology Management Unit. Bahir Dar.

Rifaee, M.A., Munir, A.T. and Abdel, R.M.T. (2004). Effect of Seed Size and Plant Population Density on Yield and Yield Components of Local Faba Bean (Vicia faba L. major). International Journal of Agriculture \& Biology, 6(2): 294-299.

Seyfu Ketema. (1997). Tef [Eragrostis tef (Zucc.) Trotter], Promoting the conservation and use of underutilized and neglected crops. 12. Institute of Plant Genetics and Crop Plant Research, Gatersleben/International Plant Genetic Resources Institute, Rome, Italy.

Tareke, B., Zewdie, G., Edwards, S., and Hailu, A. (2013). Boosting tef productivity using improved agronomic practices and appropriate fertilizer. In: Proceedings of the Second International Workshop. Kebebew, A., Solomon, C., and Zerihun, T. (Eds.). Achievements and Prospects of Tef Improvement, November 7- 9, 2011, Debre Zeit, Ethiopia. Ethiopian Institute of Agricultural Research, Addis Ababa, Ethiopia; Institute of Plant Sciences, University of Bern, Switzerland. Printed at Stampfli AG, 3001 Bern, Switzerland. pp. 133-140.

VanDelden, S. H., Vos, J., Ennos, A. R. and Stomph, T. J. (2010). Analysing lodging of the panicle bearing cereal tef (Eragrostis tef). New Phytologist, 186: 696-707. 